\title{
Post-COVID-vaccine autoimmune/inflammatory syndrome in response to adjuvants (ASIA syndrome) manifesting as subacute thyroiditis
}

\author{
${\text { L. } \operatorname{Das}^{1} \text { (D) . S. K. Bhadada }}^{1}$ (D) A. Sood ${ }^{2}$
}

Received: 10 August 2021 / Accepted: 18 September 2021 / Published online: 28 September 2021

(C) Italian Society of Endocrinology (SIE) 2021

Keywords ASIA syndrome $\cdot$ COVID vaccine $\cdot$ Subacute thyroiditis

SAT is a common thyroid-related syndrome in COVID-19 [1]. However, SAT following vaccine for SARS-CoV-2 is rare. Herein, we report the case of a 47 -year-old female who presented with fever and neck pain for 2 weeks following the first dose of the ChAdOx1 nCoV-19 (Astra Zeneca) vaccine. The fever was moderate-to-high grade, continuous, and associated with neck pain radiating to the jaw. She also complained of restlessness, difficulty in swallowing and weight loss of $3 \mathrm{~kg}$ in this duration. She was febrile and had tachycardia (110/min). Her neck examination showed a tender goitre (WHO grade II) with no palpable lymphandenopathy. Thyroid function tests (TFT) revealed thyrotoxicosis (T3 $2.2 \mathrm{ng} / \mathrm{ml}[\mathrm{N} 0.8-2 \mathrm{ng} / \mathrm{ml}], \mathrm{T} 412.9 \mu \mathrm{g} / \mathrm{dl}$ [N 4-12 $\mu \mathrm{g} /$ $\mathrm{dl}]$, TSH $0.06 \mu \mathrm{IU} / \mathrm{ml}[\mathrm{N} 0.2-4.2 \mu \mathrm{IU} / \mathrm{ml}])$. Thyroid antibodies (antiTPO $11.8 \mathrm{IU} / \mathrm{ml}[\mathrm{N}<34]$ and TRAb $1.28 \mathrm{IU} /$ $\mathrm{ml}[\mathrm{N}<1.75])$ were normal. Neck ultrasound showed a bulky thyroid with hypoechoic nodules $(1.5 \times 1.0 \mathrm{~cm}$ in the right and $0.8 \times 0.5 \mathrm{~cm}$ in the left lobe) without any cystic changes, calcification or increased vascularity. She underwent a pertechnetate $\left({ }^{99 \mathrm{~m}} \mathrm{Tc}-\mathrm{TcO}_{4}{ }^{-}\right)$thyroid scan, which revealed no tracer uptake in the thyroid gland (Fig. 1A). Fine-needle aspiration cytology of the right-sided suspicious nodule showed granulomatous inflammation. The patient was diagnosed with SAT and advised $40 \mathrm{mg}$ propranolol daily. She showed a gradual improvement in her restlessness and gained weight, besides having resolution of her neck discomfort. On re-evaluation after 8 weeks, she had complete resolution of her presenting features, with normal

S. K. Bhadada

bhadadask@rediffmail.com

1 Department of Endocrinology, Post Graduate Institute of Medical Education and Research, 1008, Nehru Extension Block, Chandigarh 160012, India

2 Department of Nuclear Medicine, PGIMER, Chandigarh, India
TFT (T3 $1.09 \mathrm{ng} / \mathrm{ml}$, T4 $7.04 \mu \mathrm{g} / \mathrm{dl}$, and TSH $1.50 \mu \mathrm{IU} / \mathrm{ml}$ ). Repeat scan showed improved trapping function (Fig. 1B). The index case depicts a classic case of autoimmune/inflammatory syndrome in response to adjuvants (ASIA syndrome) in a recipient of SARS-Co-V2 following the first dose of the COVID vaccine.

ASIA syndrome is an entity first described in 2011 by Schoenfeld [2]. Adjuvants are used to enhance the immunogenicity of vaccines, to increase both innate and adaptive immune responses. However, as a bystander phenomenon, vaccine adjuvants can induce the formation of autoantibodies or inflammation (localised or systemic), which may manifest as autoimmune/inflammatory syndromes. Though systemic inflammatory conditions are common, autoimmune thyroid disease as part of ASIA syndrome is uncommon, despite it being the most common autoimmune endocrinopathy. There are a few reports of Graves' disease, Hashimoto's thyroiditis and subacute thyroiditis (SAT) reported after the first or second dose of vaccines [3, 4].

SAT as part of ASIA syndrome is previously reported with hepatitis B, HPV and influenza vaccinations. There are very few instances of SAT following administration of COVID vaccines, and some prior reports have been confounded by concurrent presence of other factors that may be contributory for the development of SAT, such as post-partum period [5-7] (Table 1). All reported cases are females, except one [6]. ASIA has been reported as early as 3-5 days following the vaccine, until as late as 21 days, and most commonly following the first dose. However, scintigraphic evidence of SAT in a recipient of the first dose of the ChAdOx $1 \mathrm{nCoV}-19$ vaccine has never been hitherto demonstrated.

The index case suggests harbouring a high index of suspicion in recipients of the vaccine. Masking of symptoms, self-limiting nature and under-recognition may be the reasons for the very few reports of ASIA syndrome following 


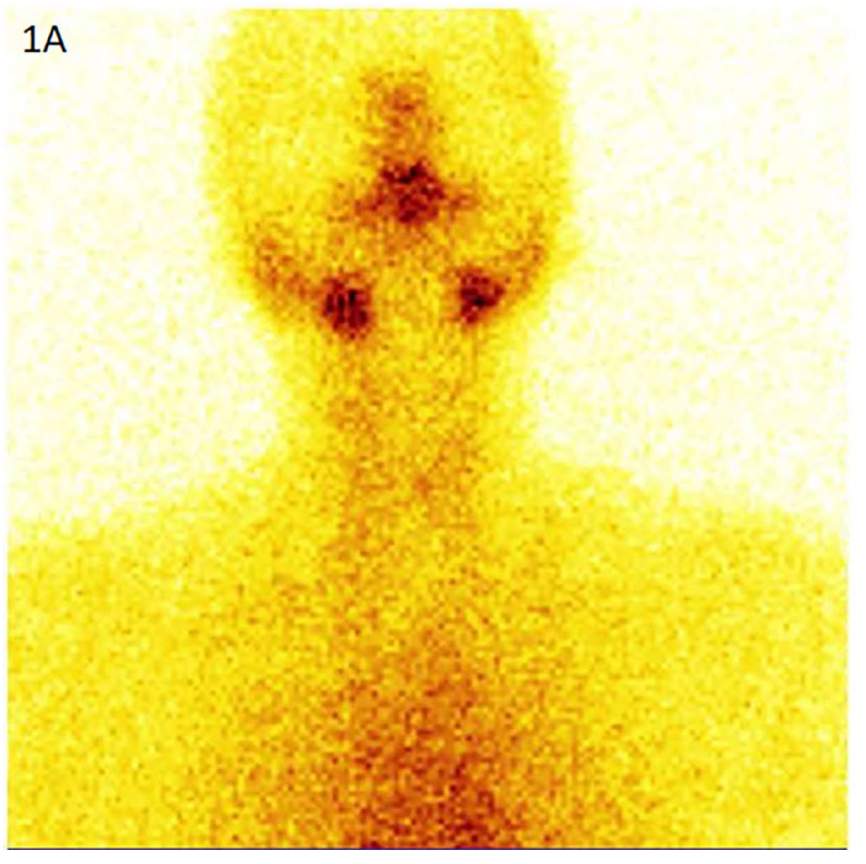

1B

Fig. $1 \mathrm{XXX}$

Table 1 Review of literature of cases of subacute thyroiditis as part of autoimmune/inflammatory syndrome in response to adjuvants (ASIA syndrome)

\begin{tabular}{|c|c|c|c|c|c|c|c|}
\hline Author & Age/Gender & Type of vaccine & Dose & $\begin{array}{l}\text { Lag period } \\
\text { of symptom } \\
\text { onset }\end{array}$ & $\begin{array}{l}\text { Ultrasonogram } \\
\text { thyroid }\end{array}$ & 99mTc TcO4- & $\begin{array}{l}\text { Additional therapy/ } \\
\text { Recovery duration }\end{array}$ \\
\hline Iremli et al. & $\begin{array}{l}35 / \mathrm{F} \\
34 / \mathrm{F} \\
37 / \mathrm{F}\end{array}$ & $\begin{array}{l}\text { Sinovac } \\
\text { (Vero } \\
\text { cell inactivated } \\
\text { whole virus) } \\
\text { Aluminium } \\
\text { hydroxide adju- } \\
\text { vant }\end{array}$ & $\begin{array}{l}\text { 2nd dose, } \\
\text { 1st dose, } \\
\text { 2nd dose }\end{array}$ & 4-7 days & $\begin{array}{l}\text { Bilateral focal } \\
\text { hypoechoic areas } \\
\text { Bilateral focal } \\
\text { hypoechoic areas } \\
\text { Bilateral focal } \\
\text { hypoechoic areas }\end{array}$ & ND & $\begin{array}{l}\text { Methylpredniso- } \\
\text { lone, propranolol/ } \\
4 \text { weeks } \\
\text { Methylpredniso- } \\
\text { lone, propranolol/ } \\
10 \text { weeks } \\
\text { No treat- } \\
\text { ment } / 8 \text { weeks }\end{array}$ \\
\hline Oyibo et al. & $55 / \mathrm{F}$ & $\begin{array}{l}\text { Astra-Zeneca } \\
\text { (adenovirus spike } \\
\text { protein compo- } \\
\text { nent vaccine) }\end{array}$ & 2nd dose & 21 days & $\begin{array}{l}\text { Enlarged heteroge- } \\
\text { neous echotex- } \\
\text { ture }\end{array}$ & ND & $\begin{array}{l}\text { Propranolol, } \\
\text { NSAIDs } \\
\text { LT4 therapy } \\
\text { required in } \\
\text { follow-up/ } \\
12 \text { weeks }\end{array}$ \\
\hline Sahin Tekin et al. & $67 / \mathrm{M}$ & $\begin{array}{l}\text { Vero-cell inacti- } \\
\text { vated } \\
\text { whole virus }\end{array}$ & 2nd dose & 10-12 days & $\begin{array}{l}\text { Enlarged het- } \\
\text { erogeneous, } \\
\text { hypoechoic } \\
\text { pseudonodules }\end{array}$ & ND & $\begin{array}{l}\text { No additional } \\
\text { therapy/8 weeks }\end{array}$ \\
\hline Current & $47 / F$ & $\begin{array}{l}\text { Astra Zeneca } \\
\text { (adenovirus spike } \\
\text { protein compo- } \\
\text { nent vaccine) }\end{array}$ & 1st dose & 21 days & $\begin{array}{l}\text { Enlarged gland, } \\
\text { heterogenous } \\
\text { echotexture, } \\
\text { hypoechoic } \\
\text { nodules }\end{array}$ & $\begin{array}{l}\text { Absent technetium } \\
\text { uptake on the } \\
\text { initial scan fol- } \\
\text { lowed by normal } \\
\text { uptake (1\%) } \\
8 \text { weeks later }\end{array}$ & $\begin{array}{l}\text { No specific } \\
\text { therapy/8 weeks }\end{array}$ \\
\hline
\end{tabular}

COVID vaccine. Though heterogeneous echotexture is the most common pattern in SAT following COVID vaccination, the index case had nodules in the presence of biochemically and scintigraphically confirmed SAT. The fact that TFT 
normalised, while thyroid scan was still improving is in line with the natural history of SAT [8]. Thyrotoxicosis temporally associated with the first dose of vaccine, scintigraphic evidence of absent uptake, with following of normalisation of symptoms, TFT and resolving uptake at 8 weeks from initial onset of disease, suggests the diagnosis of SAT due to ASIA syndrome. Probable mechanisms include the activation of autoimmune cascades, polyclonal activation of B-lymphocytes and molecular mimicry. ACE2 receptormediated mechanism is also plausible considering the fact that the ChAdOx $1 \mathrm{nCoV}-19$ is a simian-virus vectored spike protein of SARS-CoV-2 which infact binds to ACE2 and the thyroid is known to have one of the highest expression of ACE2 in follicular cells $[9,10]$.

Our case is the first case of COVID-19 vaccine-related SAT with nodular goitre proven by scintigraphic evidence at diagnosis and during recovery. Though the case represents a rare adverse inflammatory endocrinopathy following COVID vaccine, this should not deter the use of vaccination, as it can be timely diagnosed and effectively managed.

Author contributions LD and SKB were involved in clinical care of the patient. LD and SKB reviewed the literature. LD wrote the first draft. SKB and AS edited the manuscript. All authors approved the final version of the manuscript. Written informed consent was obtained from the patient.

Funding There was no source of funding for this study.

\section{Declarations}

Conflict of interest The authors have no conflicts of interest to declare.

Research involving human participants and/or animals All procedures performed were in accordance with the ethical standards of the institutional and/or research committee and with the 1964 Helsinki Declaration and its later amendments or comparable ethical standards. The ethical committee approval is not required for case reports.

Informed consent Written, informed consent was obtained from the patient for participation and publication.

\section{References}

1. Christensen J, O'Callaghan K, Sinclair H, Hawke K, Love A, Hajkowicz K, Stewart AG (2021) Risk factors, treatment and outcomes of subacute thyroiditis secondary to COVID-19: a systematic review. Internal Med J. https://doi.org/10.1111/imj.15432

2. Watad A, David P, Brown S, Shoenfeld Y (2016) Autoimmune/ inflammatory syndrome induced by adjuvants and thyroid autoimmunity. Front Endocrinol (Laussane) 7:150. https://doi.org/10. 3389/fendo.2016.00150

3. Bragazzi NL, Hejly A, Watad A, Adawi M, Amital H, Shoenfeld Y (2020) ASIA syndrome and endocrine autoimmune disorders. Best Pract Res Clin Endocrinol Metabol 34:101412. https://doi. org/10.1016/j.beem.2020.101412

4. Vera-Lastra O, Ordinola Navarro A, Cruz Domiguez MP, Medina G, Sánchez Valadez TI, Jara LJ (2021) Two cases of Graves' disease following SARS-CoV-2 vaccination: an autoimmune/inflammatory syndrome induced by adjuvants. Thyroid. https://doi.org/ 10.1089/thy.2021.0142

5. İremli BG, Şendur SN, Ünlütürk U (2021) Three cases of subacute thyroiditis following SARS-CoV-2 vaccine: post-vaccination asia syndrome. J Clin Endocrinol Metab. https://doi.org/10.1210/ clinem/dgab373

6. Oyibo SO (2021) Subacute Thyroiditis After Receiving the Adenovirus-Vectored Vaccine for Coronavirus Disease (COVID-19). Cureus 13:16045. https://doi.org/10.7759/cureus.16045

7. Şahin Tekin M, Şaylısoy S, Yorulmaz G (2021) Subacute thyroiditis following COVID-19 vaccination in a 67-yearold male patient: a case report. Hum Vaccin Immunother 10(1080/21645515):1947102

8. Hennessey J. Subacute thyroiditis. Endotext [Internet]. 2018

9. Das L, Dutta P, Walia R, Mukherjee S, Suri V, Puri GD, Mahajan V, Malhotra P, Chaudhary S, Gupta R, Jayant SS (2021) Spectrum of endocrine dysfunction and association with disease severity in patients with COVID-19: insights from a cross-sectional, observational study. Front Endocrinol (Laussane) 12:645787. https:// doi.org/10.3389/fendo.2021.645787

10. Rotondi M, Coperchini F, Ricci G, Denegri M, Croce L, Ngnitejeu ST, Villani L, Magri F, Latrofa F, Chiovato L (2021) Detection of SARS-COV-2 receptor ACE-2 mRNA in thyroid cells: a clue for COVID-19-related subacute thyroiditis. J Endocrinol Invest 44(5):1085-1090

Publisher's Note Springer Nature remains neutral with regard to jurisdictional claims in published maps and institutional affiliations. 